$12^{\circ}$ of the sun's place. The very slow motion of the meteor, its considerable length of path, and the exceptional point from which it diverged, combine to render it an object of especial interest, and further observations of its apparent path would be valuable. It probably became visible at an earlier part of its path than when first seen at Bristol in Lyra, and it is desirable to ascertain, if possible, a more precise result for its point of dppearance. The entire length of its course misht then be derived, when it would possibly be found that the distance assigned from present data is much shorter than that really traversed by the meteor. The Bristol and Reading observations indicate the whole length as nearly 300 miles, and this, though undoubtedly under the true value, is yet far greater than the customary tracks over which the flights of these bodies extend.

Bristol, May 3r.

W. F. LENNING.

Palæolithic Implements from the Hills near Dunstable.

DURING the past twelve months $I$ have found a small number of Palæolithic implements at great elevations in North Hertfordshire and South Bedfordshire, unconnected with existing river valleys. Four of the implements -1 386, 1387, 1393, and 1 398 in my collection-are from Caddington : height above Ordnance datum, 595 feet 9 inches. The dry valley close by, to the west, is 470 feet, and the ground gradually falls southwards to 409 feet at the source of the Ver, near Markyate Street, at a distance of $\mathbf{I}^{\frac{3}{4}}$ mile. The sections at Caddington exhibit red "clay with fints," brick earth (or clay), and tenacious brown clay or loam, surmounted by blackish earth, containing broken white-coated Aints, a few ochreous flints, and numerous blackish Tertiary pebbles. The whole deposit rests on chalk, and varies in depth from 2 feet to 50 feet. A ware of the importance of finding the worked flints in the undisturbed material, I have, after long searching, found a single implement and one or two flakes in situ at the stony bottom of the upper deposit of tenacious brown slay at a depth of 3 and 4 feet from the surface. A single smal Palæolithic implement I have found on the surface at Kensworth height above Ordnance datum, 759 feet 8 inches. The bottom of the valley, $\mathrm{I} \frac{1}{4}$ mile to the west, at the source of the Onzel, is $4 \mathrm{I} 4$ feet. Half an ovate Palæolithic implement, obviously derived from the hill-tops, I have found in a field at the bottom of a chalky valley near Houghton Regis. The Caddington implements are pointed (or tongue-shaped), slightly abraded, small in size, and cinnamon-brown in colonr. The interest attached to these finds rests not only on the great heights mentioned and the positions away from existing river valleys, but in the nature, age, and mode of deposit of the upper tenacious brown clay in which the implements are embedded. The imple ments themselves agree in make and appearance with the wellknown brown or ochreous implements often found in non-ochreous sand, \&c., in existing river valleys. I have at present seen no traces of fossil bones or fresh-water shells in the deposits mentioned.

Dunstable.

\section{Japanese Clocks.}

WI'r reference to your notice of the Japanese clocks purchased for this Museum, and described by Mr. A. Rambaut, it may prove of interest to point out in somewhat fuller detail the conclusions at which he has arrived as to the cause of the peculiarities in their construction It was on account of these, to me, unintelligible peculiarities, that I invited Mr. Rambaut to undertake their explanation, and this, I venture to think, he has very thoroughly accomplished as follows. The three clocks agree in having a dial on which the time is indicated by a pointer attached to, and descending with, the weights. In other respects they differ, though all are made more or less on the same principle. The largest of the three appears the most important, and the greater part of the paper is occupied in explaining its construction. The dial of this is divided by vertical lines int six equal spaces, which are crossed by a series of thirteen graceful curves. An examination of these curves leads to the conclusion that they were intended to divide the day and night, a all seasons of the year, into six equal portions each. This system was common enough in ancient times, but the peculiarity of these clocks is that they show the day to have been reckoned, not from sunrise till sunset, but from the first noticeable streak of morning twilight until the sun had reached a corresponding distance below the western horizon. This distance is equal to $13^{\circ}$, and the form of the curves leads to the conclusion that the clock was constructed in a latitude of about $34^{\circ} 7^{\prime}$, very little less than that of Miako, formerly one of the principal cities in Japan. An examination of the two other clocks, although they differ very much in detail, supports the conclusions derived from a study of the first.

Science and Art Museum, Dublin, June I.

\section{Luminous Night-Clouds.}

FOR the first time this year these clouds appeared in this locality last night, between Io p.m. and midnight. I inclose sketches, as with my reports in former years, made at half-hour intervals, exhibiting development and movement; which latter has been in this case from west to east, a direction the reverse of light local wind. A depression of temperature was noticed, as on former occasions. Minimum (on grass) fell to $40^{\circ} \mathrm{F}$.

It may be remembered by some of your readers that when first pointing attention to this annual phenomenon some years ago, and affirming the self-luminous character of these cloudlets, at apparently high altitudes, the name "nubeculæe boreales" was suggested to distinguish them from simple auroral effects. Herr Jesse, of Berlin, has recently (NATURE, vol. xxxix. p. 537) noted their occurrence toward the South Pole also, and pointed to their probable cosmical importance. Detailed observations of any of your correspondents, made during the present reappearance of this phenomenon, would be accepted by the writer thankfully, toward a fuller discussion of the subject. If, as wonld appear, it is chiefly of a Polar character, the name proposed should be modified to include the South Pole, and these clouds so designated "nubeculæ polares" (or "noctilucæ")

Dundrum, Co. Dublin, June 8.

$$
\text { D. J. Rowan. }
$$

\section{Note on some Hailstones that fell at Liverpool on Sunday, June 2, I889.}

BeIvg in the Physical Laboratory at about $3.35 \mathrm{p} . \mathrm{m}$, ahout which time a violent thunderstorm took place, accompanied by hail and rain, I went outside and picked up what seemed to me a fine specimen of hail. I brought it inside, mensured its diameter with a pair of calipers, and found it to be 2.9 centimetres.

I then placed it on a slate slab, on which it gradually melted down until it showed a very fine section, a picture of which is given below.

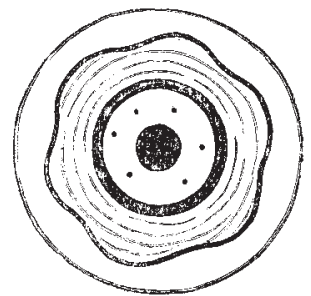

The centre was circular, and consisted of opaque ice, about the size of an ordinary hailstone; this was surrounded by a circle of almost perfectly clear ice, this again by a circle of opaque ice, and this once more was surrounded by almost clear ice, but with fine circular lines in it, and bounded by a beautifully filled outline of opaque ice, which imitated in shape the spheroidal state of a cirop of water. Outside this again was a thick layer of clear ice of crystalline form, the position of whose angles I have not shown, as I did not observe their position with regard to the frill inside sufficiently well.

The diagram is drawn to the right size, omitting the angles on the outer covering of ice, the dark parts represent white opaque ice.

If a hailstone is furmed during electric oscillation from cloud to cloud, and if it receives opaque ice from one cloud and clear ice from another, the alternation of layers would be a natural consequence. The violence of the hail scarcely seemed as great as their size justified, and this suggested that electrostatic attraction had upheld them against the force of gravitation down to a moderate height above the ground.

I believe almost all the lightning flashes that occurred were between two clouds, as, although I was looking out for the form of the flashes, I could only see the sky lit up with a brilliant red 